\title{
The Relationship of CD4 Cells and History of Diarrhea to Cryptosporidium sp. and Giardia lamblia Infections in HIV/AIDS Patients in West Sumatra Indonesia and its DNA Isolation
}

\author{
Nuzulia Irawati ${ }^{1}$, Goldha Faroliu ${ }^{2} *$ and Zahra Frizki Asty ${ }^{2}$ \\ ${ }^{1}$ Parasitology Laboratory, Faculty of Medicine, Andalas University, Padang 25138, Indonesia \\ ${ }^{2}$ Biomedical Sains, Faculty of Medicine, Andalas University, Padang 25138, Indonesia \\ *Corresponding author
}

\begin{tabular}{|l|}
\hline K e y w o r d s \\
Cryptosporidium \\
sp., Giardia \\
lamblia, history of \\
diarrhea, \\
HIV/AIDS, CD4 \\
cells
\end{tabular}

\section{A B S T R A C T}

Opportunistic infections are infections that occur due to a decrease in the immune system and can cause serious conditions in people with weak immune systems such as in people with HIV / AIDS. Cryptosporidium sp. and Giardia lamblia are examples of the opportunistic intestinal protozoa that can cause chronic diarrhea so that it becomes dehydrated and malnutrition which can increase mortality and morbidity in HIV sufferers. Observational study with cross-sectional design on 50 fecal samples of HIV / AIDS patients. Cryptosporidium sp. and Giardia lamblia infections tested microscopically using Ziehl Neelsen's staining and molecular examination with DNA isolation, and looking at the relationship between CD4 cell counts and history of diarrhea with Cryptosporidium sp.and Giardia lamblia infections. The results obtained 2 respondents (4\%) positive infected with Cryptosporidium sp., There is a significant relationship between CD4 cell counts with Cryptosporidium sp. infection, $\mathrm{p}$-value $=0.001 \quad(\mathrm{p}<0.05)$ and there is a significant relationship between Cryptosporidium sp.infections with a history of diarrhea, $\mathrm{p}$-value $=0.045(\mathrm{p}<0.05)$. And obtained 1 respondents $(2 \%)$ positive infected with Giardia lamblia, There is no significant relationship between CD4 cell counts with Giardia lamblia. infection, p-value $=1.000(\mathrm{p}>0.05)$ and there is a significant relationship between Giardia lamblia infections with a history of diarrhea, $p$-value $=0.031(\mathrm{p}<0.05) .18$ out of 50 samples have been successfully carried out the process of isolating DNA specifically thick cell walled microorganisms.

\section{Introduction}

HIV is a type of virus that attacks the human immune system, especially CD4 T lymphocyte cells, with a decrease in immune status (CD4) can make various microorganisms such as bacteria, viruses, protozoa, and fungal tend to grow and multiply causing secondary infections (Mandal, 2008). 
From UNAIDS (United Nation Programme on HIV/AIDS) data, cases of HIV/AIDS in the world is increase. In 2018 around 37.9 million HIV patients were discovered in the world, with 1.7 million new patients and 770,000 dying from AIDS. Asia Pacific increased from the third position in 2017 to second place in 2018 with the number of patients reaching 5.9 million, with 310,000 new patients, and 200,000 suffering from AIDS (UNAIDS, 2019). In Indonesia, the number of HIV/AIDS cases has increased compared to the last 10 years, while West Sumatra ranks eleventh (UNAIDS, 2018; Health Ministry of Indonesia, 2018).

An increase in HIV/AIDS cases is followed by an increasing number of cases of opportunistic infections that occur due to a decrease in the immune system (Agarwal, et $a l ., 2015)$. One of the opportunistic infections that still causes high rates of morbidity and mortality in people with HIV/AIDS is diarrhea, in individuals with immune deficiencies often results in mild to severe symptoms resulting in chronic diarrhea and can increase in the mortality rate of HIV patients (Prasetyo, 2015 ).

One of the main agents causing diarrhea in HIV/AIDS patients is intestinal parasites. Intestinal protozoa that often cause disease in HIV patients include Entamoeba histolytica, Cryptosporidium sp., and Giardia lamblia (Deb et al, 2015). HIV/AIDS patients who have a CD4 cell $\leq 200$ cells $/ \mu$ l become easily infected with intestinal protozoa and cause severe clinical symptoms, such as diarrhea.

Cryptosporidium sp. is the most parasite found in the stool of HIV patients (Wahdini et $a l, 2016)$. In the research of Masarat (2012) found $80 \%$ of cases of cryptosporidiosis in HIV patients. Giardia infection can also increase due to a lower CD4 cell count, especially in patients infected with HIV
(Daryani, Sharif \& Meigouni, 2009). In a study of 75 HIV-infected adults in India, $G$. lamblia was the most commonly isolated parasite, and patients with lower CD4 cell counts had more enteric disease and chronic diarrhea (Dwivedi et al, 2007).

Along with the increase in cases of HIV/AIDS and chronic diarrhea as one of the most common opportunistic infections, the incidence of Cryptosporidium sp. and Giardia lamblia needs to be investigated.

\section{Materials and Methods}

In this study, 50 faecal samples from HIV/AIDS patients from Dr. M. Djamil Padang Hospital Indonesia. Samples were examined microscopically by modified Ziehl Neelsen's acid-resistant staining and molecular examination by isolating microorganism DNA specifically with thick cell walls using QIAamp® Fast DNA Stool Mini kits (InhibitEX Buffer, Proteinase K, Buffer AL, Buffer AW1, Buffer AW2, Buffer ATE) Qiagen ${ }^{\circledR}$.

\section{Results and Discussion}

In this study, 50 respondents with HIV/AIDS were obtained from the Dr. M. DjamilPadang Hospital. Respondent with the lowest CD4 cell count of 5 cells $/ \mu \mathrm{L}$ and highest CD4 cell count of 350 cells $/ \mu \mathrm{L}$, and with a history of diarrhea in the last 2 weeks of 11 people $(22 \%)$. In this study, respondents who were positive infected withCryptosporidium sp.and Giardia lamblia had a history of diarrhea in the past 2 weeks.

Based on the research conducted, microscopic examination (Table 1) found a total detected by Cryptosporidium $s p$. as many as 2 respondents (4\%) and 1 respondent (2\%) were detected infected with Giardia lamblia. 
On microscopic examination found Cryptosporidium sp.oocysts with round shape almost resembles an oval measuring 4-6 micrometers. And also found an oval-shaped Giardia lamblia cyst that has a length of about 8-12 microns, has a thin and strong wall. The cytoplasm is fine-grained and is clearly separated from the cyst wall. Then the cyst found clearly has 2 nucleus.

\section{Cryptosporidium sp. and Giardia lamblia} microscopically tested with Ziehl Neelsen's acid-resistant staining. The Ziehl-Neelsen staining was chosen because it is a method choice that is quite simple, inexpensive, and provides quite high sensitivity. ZiehlNeelsen's examination serves to determine the reaction of microorganism cell walls through a series of staining. Groups of acid-resistant bacteria and other microorganisms that have lipid content in cell wall are so thick that they cannot be colored with ordinary coloring reactions, but must be with acid-resistant staining and can maintain dyes when washed with a pale solution. In thick cell wall microorganisms, the cell walls are dehydrated by alcohol treatment, pores shrink, cell wall permeability and membranes decrease so that the methylene blue dye cannot enter so that microorganisms with thick cell wall will remain red in color.

In this study the results of the examination of Cryptosporidium sp. using Ziehl-Neelsen was obtained 2 respondents (4\%) positively infected with Cryptosporidium $s p$. with average of CD4 cell count was $150 \pm 0$ cells $/ \mu \mathrm{L}$, while the average CD 4 cell count in respondents who were negative for Cryptosporidium sp. infection was $206.79 \pm 110.668$ cells $/ \mu \mathrm{L}$, from the results of statistical tests using the Independent Sample T-Test to determine the relationship between CD4 cell counts and Cryptosporidium $s p$. infection with $\mathrm{p}$-value $=0.001 \quad(\mathrm{p}<0.05)$ showed a relationship between CD4 cell count and Cryptosporidium sp. infection. With a significant difference between CD4 cell counts in respondents who were positive infected with Cryptosporidium sp. with respondents who were negative infected with Cryptosporidium sp.In accordance with the research of Mitra et al (2016), respondents with CD4 counts $\leq 350$ cells $/ \mu \mathrm{L}$ were more infected with Cryptosporidium sp. compared to other parasites.

In a previous study, examination of Giardia lamblia in HIV patients with a CD4 cell count of $\leq 200$ cells $/ \mu \mathrm{L}$ obtained a positive total of 3 (3\%) from 100 samples (Gupta el al, 2013). Accordance with Obateru et al (2016) that from the results of his research on Giardia lamblia examination in HIV sufferers with a CD4 cell count of $\leq 200$ cells $/ \mu \mathrm{L}$, a total of 9 positive people $(3.7 \%)$ were found, especially in individuals with HIV infection at risk of Giardia lamblia infection if CD4 $\leq 400$ cells/ $\mu \mathrm{L}$ (Faria et al, 2017). Statistical tests for the relationship of CD4 cell counts with Giardia lamblia infection obtained p-value $=$ 1,000 ( $p>0.05$ ), which showed no significant relationship between CD4 cell counts and Giardia lamblia infection. In accordance with the research of Samuel et al (2017) relationship between the number of CD4 cells with Giardia lamblia infection obtained pvalue $=0.852$ which indicates there is no significant relationship between the number of CD4 cells with Giardia lamblia infection.

In this study, respondents who had a history of diarrhea in the last 2 weeks, 2 out of 50 respondents $(4 \%)$ in patients with a history of diarrhea positively infected with Cryptosporidium sp., and 1 out of 50 respondents $(2 \%)$ in patients with a history of diarrhea positively infected withGiardia lamblia (Table 2), based on statistical tests showing a significant relationship between Cryptosporidium sp.and Giardia lamblia infections with a history of diarrhea. 
Table.1 Relationship of CD4 Cell Counts with Cryptosporidium sp. and Giardia lamblia Infections

\begin{tabular}{|c|c|c|c|}
\hline Result & $\mathbf{N}$ & $\begin{array}{c}\text { Mean } \pm \text { SD } \\
\text { CD4 }(\text { cells } / \mu \mathrm{L})\end{array}$ & $p$-value \\
\hline \multicolumn{4}{|c|}{ Cryptosporidium sp. } \\
\hline Positive & 2 & $150 \pm 0$ & \multirow[t]{2}{*}{0,001} \\
\hline Negative & 48 & $206,79 \pm 10,67$ & \\
\hline \multicolumn{4}{|c|}{ Giardia lamblia } \\
\hline Positive & 1 & $150 \pm 0$ & \multirow[t]{2}{*}{1.000} \\
\hline Negative & 49 & $205,63 \pm 11,48$ & \\
\hline
\end{tabular}

Table.2 Relationship of Cryptosporidium sp. and Giardia lamblia with a history of diarrhea

\begin{tabular}{|c|c|c|c|c|}
\hline \multirow{2}{*}{ Result } & \multicolumn{2}{|c|}{ History of Diarrhea } & \multirow{2}{*}{$\begin{array}{c}\text { Total } \\
(\%)\end{array}$} & $\boldsymbol{p}$ \\
\cline { 2 - 4 } & Present & No & $(\%)$ & \\
\hline Cryptosporidium sp. & $2(4 \%)$ & $0(0 \%)$ & $2(4 \%)$ & 0,045 \\
\hline Giardia lamblia & $1(2 \%)$ & $0(0 \%)$ & $1(2 \%)$ & 0.031 \\
\hline Negative (\%) & $9(18 \%)$ & $39(78 \%)$ & $48(96 \%)$ & \\
\hline
\end{tabular}

Table.3 DNA Isolation

\begin{tabular}{|r|c|c|c|}
\hline No & $\begin{array}{c}\text { Nucleid Acid } \\
\text { Conc. }(\mathbf{n g} / \mathbf{u l})\end{array}$ & $\mathbf{2 6 0} / \mathbf{2 8 0}$ & $\mathbf{2 6 0} / \mathbf{2 3 0}$ \\
\hline $\mathbf{1}$ & 1,8 & 0,33 & 0,01 \\
\hline $\mathbf{2}$ & 1,2 & 0,44 & 0,01 \\
\hline $\mathbf{3}$ & 14,5 & 3,59 & 0,06 \\
\hline $\mathbf{4}$ & 1,8 & 0,62 & 0,01 \\
\hline $\mathbf{5}$ & 4,7 & 2,66 & 0,03 \\
\hline $\mathbf{6}$ & 10 & 5,69 & 0,05 \\
\hline $\mathbf{7}$ & 12,4 & 2,86 & 0,09 \\
\hline $\mathbf{8}$ & 6,8 & 10,49 & 0,05 \\
\hline $\mathbf{9}$ & 0,6 & 0,11 & 0 \\
\hline $\mathbf{1 0}$ & 7,2 & 10,72 & 0,05 \\
\hline $\mathbf{1 1}$ & 3,3 & 1,98 & 0,03 \\
\hline $\mathbf{1 2}$ & 2,7 & 1,05 & 0,02 \\
\hline $\mathbf{1 3}$ & 0,4 & 0,08 & 0 \\
\hline $\mathbf{1 4}$ & 1,6 & 0,44 & 0,01 \\
\hline $\mathbf{1 5}$ & 2,4 & 0,59 & 0,02 \\
\hline $\mathbf{1 6}$ & 3,6 & 1,59 & 0,03 \\
\hline $\mathbf{1 7}$ & 2,5 & 0,87 & 0,02 \\
\hline $\mathbf{1 8}$ & 5,5 & 5,65 & 0,04 \\
\hline $\mathbf{1 9}$ & 26,1 & 4,98 & 0,1 \\
\hline $\mathbf{2 0}$ & 21,4 & 4,9 & 0,16 \\
\hline $\mathbf{2 1}$ & 30,1 & 2,86 & 0,2 \\
\hline & & & \\
\hline
\end{tabular}




\begin{tabular}{|c|c|c|c|}
\hline $\mathbf{2 2}$ & 34,3 & 2,78 & 0,21 \\
\hline $\mathbf{2 3}$ & 19,6 & 4,71 & 0,14 \\
\hline $\mathbf{2 4}$ & 8,4 & 5,92 & 5,92 \\
\hline $\mathbf{2 5}$ & 7,7 & 5,04 & 0,05 \\
\hline $\mathbf{2 6}$ & 0,6 & 0,12 & 0 \\
\hline $\mathbf{2 7}$ & 0 & 0 & 0 \\
\hline $\mathbf{2 8}$ & 2,5 & 0,61 & 0,02 \\
\hline $\mathbf{2 9}$ & 19,1 & 4,7 & 0,14 \\
\hline $\mathbf{3 0}$ & 1,9 & 0,54 & 0,01 \\
\hline $\mathbf{3 1}$ & 5,7 & 4,22 & 0,04 \\
\hline $\mathbf{3 2}$ & 1,8 & 0,5 & 0,01 \\
\hline $\mathbf{3 3}$ & 11,1 & 9,32 & 0,08 \\
\hline $\mathbf{3 4}$ & 0,1 & 0,02 & 0 \\
\hline $\mathbf{3 5}$ & 6,6 & 4.73 & 0,05 \\
\hline $\mathbf{3 6}$ & 13,5 & 2,39 & 0,1 \\
\hline $\mathbf{3 7}$ & 7 & 13,11 & 0,05 \\
\hline $\mathbf{3 8}$ & 24,8 & 3,64 & 0,17 \\
\hline $\mathbf{3 9}$ & 0 & 0 & 0 \\
\hline $\mathbf{4 0}$ & 28,2 & 2,98 & 0,19 \\
\hline $\mathbf{4 1}$ & 24,2 & 3,54 & 0,17 \\
\hline $\mathbf{4 2}$ & 0,3 & 0,06 & 0 \\
\hline $\mathbf{4 3}$ & 5,4 & 2,3 & 0,04 \\
\hline $\mathbf{4 4}$ & 10,3 & 6,57 & 0,07 \\
\hline $\mathbf{4 5}$ & 6,9 & 7,01 & 0,05 \\
\hline $\mathbf{4 6}$ & 63,3 & 2,42 & 0,41 \\
\hline $\mathbf{4 7}$ & 27,4 & 2,6 & 0,17 \\
\hline $\mathbf{4 8}$ & 47,3 & 2,53 & 0,29 \\
\hline $\mathbf{4 9}$ & 29,4 & 3,17 & 0,2 \\
\hline $\mathbf{5 0}$ & 9,9 & 14,12 & 0,07 \\
\hline & & & \\
\hline
\end{tabular}

Fig 1. Microscopic results of Giardia lamblia(1000x magnification)

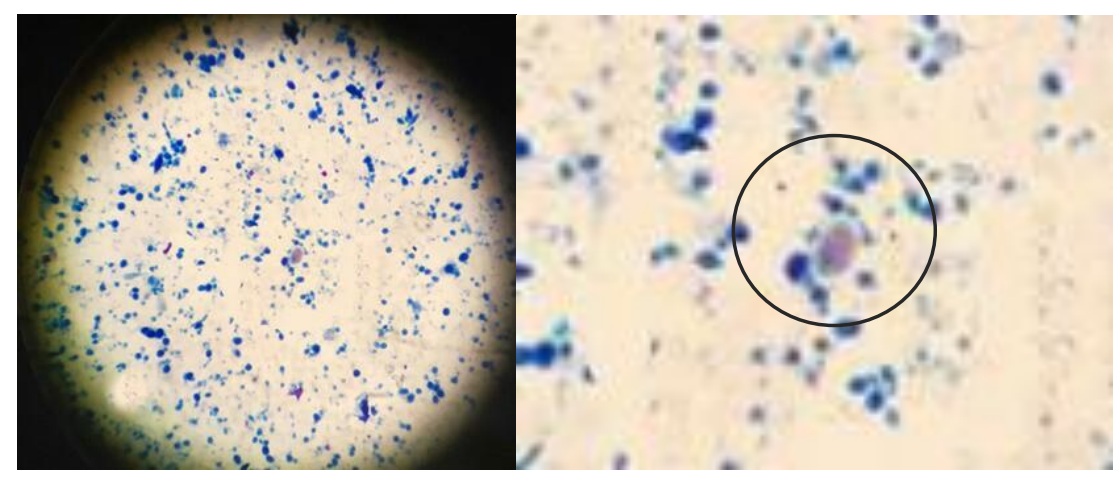


Fig 2. Microscopic results of Cryptosporidium sp. (1000x magnification)

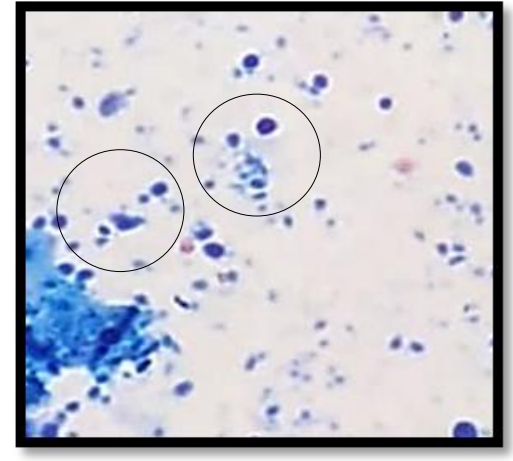

In the molecular examination, DNA isolation is carried out in the sample. DNA isolation uses a special procedure to isolate DNA from faecal samples for pathogen detection based on the QIAamp Fast DNA Stool Mini Handbook protocol, where there is a difference in treatment compared to ordinary DNA isolation, ie with $90-95^{\circ} \mathrm{C}$ heating after the sample is dissolved with the InhibitEX Buffer, it aims to helps lysis of bacteria (Gram Positive), parasites, or other microorganisms that have thick cell walls and are difficult for lysis. Furthermore, the results of DNA isolation were examined for the purity and concentration of DNA using Nanodrop. DNA isolates with high concentrations have good purity.

In this study, 18 out of 50 samples had high DNA concentrations above $10 \mathrm{ng} / \mu \mathrm{l}$, because through the DNA isolation process specifically thick cell walled microorganisms, it was suspected that the isolated DNA might originate from thick cell walled microorganisms such as intestinal parasites.

\section{References}

Agarwal, S.G., Powar, R.M., Tankhiwale, S., Rukadikar, A. 2015. Study of opportunistic infections in HIV-AIDS patients and their co-relation with CD4+ cell count. Int J Curr Microbiol App Sci, 4(6): 848-61.
Bachur TP, Vale JM, Coelho IC, Queiroz TR, Chaves Cde S. Enteric parasitic infections in HIV/AIDS patients before and after the highly active antiretroviral therapy. Braz $J$ Infect Dis. 2008;12(2):115-122.

Departemen Kesehatan RI .2018. Profil HIV di Indonesia. Jakarta: Depkes

Deb M, Joseph A, Khalil S, Mirdha BR, Panda A, Sinha SSY. 2015. Intestinal parasitosis in relation to ART, CD4 Tcell count and diarrhea in HIV patients. Korean $J$ Parasitol. 2015;53(6): 705-712.

Erickson MC, Ortega YR. Inactivation of protozoan parasites in food, water, and environmental systems. J Food Prot. 2006;69(11):2786-2808.

Faria CP, Zanini GM, Dias G2, Sousa MDC. Associations of Giardia lamblia assemblages with HIV infections and symptomatology: HIV virus and assemblage B were they born to each other. Journal of Medicine Institutes of Health. 2017; 11(8).

Gupta, K, Bala, M, Sharma, DK. Prevalence of Intestinal Parasitic Infections in HIVInfected Individuals and Their Relationship with Immune Status. Indian Journal of Medical Microbiology. 2013; 31(2): 161-165.

Ministry of Health of Indonesia. 2018. Hari AIDS Sedunia, Momen STOP Penularan HIV: Saya Berani, Saya 
Sehat!. Jakarta: Ministry of Health of Indonesia.

Mandal, A. 2008. AIDS Pathophysiology. News Medical Life Sciences, pp: 10 -13.

Masarat, S., Ahmad, F., Chisti, M., Sofi, B., and Ahmad. 2012. Prevalence of Cryptosporidium species among HIV positive asymptomatik immigrant population in Kashmir, India. Iranian Journal of Microbiology, 4 (1):34-38.

Obateru, O.A, Bojuweyo,B.J, and Olokoba, AB. 2016. Prevalence of Intestinal Parasites in Newly Diagnosed HIV/AIDS Patients in Ilorin, Nigeria. Alexandria of Medicine Journal. 2016; 53(2): 111-116.

Pavie J, Menotti J, Porcher R, Donay JL, Gallien S, Sarfati C, Derouin F, Molina JM. Prevalence of Opportunistic Intestinal Parasitic Infections among HIV-Infected Patients with Low CD4 cells counts in France in The Combination Antiretroviral Therapy Era. International Journal of Infectious
Disease. 2012; 16(9): 677-679.

Prasetyo, H. 2015. Infeksi Parasit Usus Oportunistik. http://repository.unair.ac.id/55064/

Rochelle PA, Leon RD, Stewart MH, Wolfe RL. 1997. Comparison of Primers and Optimization of PCR Conditions for Detection of Cryptosporidium parvum and Giardia lamblia in Water. Appl Environ Microbiol; 63(1): 106-114

Samuel CK, Eric NO, Badu K. Intestinal Parasitemia and HIV/AIDS Coinfections at Varying CD4+ T-cell Levels. Journal of HIV/AIDS Research And Treatment. 2017; 4(1): 40-48.

[UNAIDS] United Nations Programme on HIV and AIDS. 2019

Wahdini, S., Kurniawan, A., dan Yunihastuti, E. 2016. Deteksi Koproantigen Cryptosporidiumsp pada Pasien HIV/AIDS dengan Diare Kronis. 4(1):49-53.

WHO. 2018. HIV and AIDS: WHO

\section{How to cite this article:}

Nuzulia Irawati, Goldha Faroliu and Zahra Frizki Asty. 2020. The Relationship of CD4 Cells and History of Diarrhea to Cryptosporidium sp. and Giardia lamblia Infections in HIV/AIDS Patients in West Sumatra Indonesia and Its DNA Isolation. Int.J.Curr.Microbiol.App.Sci. 9(01): 2352-2358. doi: https://doi.org/10.20546/ijcmas.2020.901.268 